\title{
Direct-to-consumer advertising: end the compromise
}

$\mathrm{D}$ espite federal regulations forbidding direct-toconsumer advertising for drugs and medical devices, it has become commonplace in Canada. From the pages of People, Ladies' Home Journal, Redbook and other US-based publications, you can glean how to protect your young daughter from the ravages of HPV, protect yourself from a future myocardial infarction with Plavix or Crestor, or minimize joint destruction and pain from rheumatoid arthritis using new monoclonal antibodies - all while you wait to pay for groceries. You can also hear the pharmaceutical spin about new therapies while watching reruns of Friends or Law and Order on major American television channels that are widely shown in Canada by satellite or cable providers.

Apparently, direct-to-consumer advertising is prohibited only for Canadian media and businesses. ${ }^{1}$ In an odd approach to implementing its rules, Health Canada allows cryptic advertisements that either name the medical condition or the product, but not both. American companies, on the other hand, advertise with impunity in Canada. In fact, they operate under American rules in Canada. In the United States, advertisements are industry-regulated and monitored only after the fact by the US Food and Drug Administration (FDA). The FDA issues letters to companies that violate rules, mostly because the advertising campaigns overstate efficacy and minimize risk. ${ }^{2}$

Globally, only the United States and New Zealand allow direct-to-consumer drug advertising. Elsewhere, laws aim to ensure that vulnerable patients are not subjected to biased or embellished claims from drug manufacturers. Canada's approach is distinctly odd: regulations are not enforced, advertisements are not screened, and Health Canada has turned a blind eye to consumer drug advertising emanating from the United States. In effect, this has allowed Canadians to be bombarded by American pharmaceutical advertisements, while it is forbidden for Canadian businesses to advertise similarly.

This double standard makes no sense to us, and the courts may well concur.

CanWest Global Media, one of Canada's largest media conglomerates, is suing the Canadian government, claiming that the current laws and regulations violate its right to free expression, which is embedded in the Canadian Charter of Rights and Freedoms. Ironically, its case may be strengthened by Health Canada's current inaction, which allows direct-to-consumer advertising into the country - provided it originates elsewhere.

Arguments against direct-to-consumer advertising of prescription drugs centre on the public safety imperative. ${ }^{3}$ Advertising campaigns lead to more requests for the advertised medicines and more prescriptions. Often these newer drugs are more expensive, and their risk-benefit profile is not fully understood. Some $20 \%$ of all new drugs eventually receive black-box warnings. ${ }^{4}$ This is because medicines and devices are initially evaluated under ideal situations involving a limited number of patients. Under usual care conditions, the risks are often greater and the benefits fewer.

Supporters of consumer drug advertising say these advertisements inform the educated patient about alternatives to care and promote greater health literacy among consumers. ${ }^{5}$ However, let's remember that one of the pharmaceutical industry's main goals is to increase shareholder value. As a result, advertising campaigns will never be free of real or perceived biases. Educating the public about the risks and benefits of health interventions may be a secondary benefit of consumer advertising, but the bias remains.

Patient education is the domain of physicians and other health professionals, who should provide evidence-based recommendations. To support patients and health professionals in their decision-making, we need widely available sources of unbiased information about devices and drugs, not more advertising campaigns.

In the interest of fairness and public health, Health Canada must consistently enforce its current regulations on direct-toconsumer advertising, regardless of the country of origin. If Health Canada does not act, the courts may well decide for us and remove the prohibition on made-in-Canada direct-toconsumer drug advertising. Public health and consumer safety may be sacrificed in the hope of levelling the business playing field in a quintessential Canadian compromise.

\section{Paul C. Hébert MD MHSc}

Editor-in-Chief

CMAJ

With the Editorial-Writing Team (Rajendra Kale MD, Matthew B. Stanbrook MD PhD, Barbara Sibbald BJ, Ken Flegel MDCM MSc, Noni MacDonald MD MSc and Amir Attaran LLB DPhil)

Competing interests: See www.cmaj.ca/misc/edboard.shtml.

\section{REFERENCES}

1. Food and drugs act: an act respecting food, drugs, cosmetics and therapeutic devices. RS (1985) c F-27. Available: http://laws.justice.gc.ca/en/ShowFullDoc/cs/F27///en?noCookie (accessed 2008 June 12).

2. Mintzes B. Direct-to-consumer advertising or prescription drugs in Canada: What are the public health implications? Toronto (ON): Health Council of Canada; 2006

3. Mintzes B, Barer ML, Kravitz RL, et al. How does direct-to-consumer advertising (DTCA) affect prescribing? A survey in primary care environments with and without legal DTCA. CMAJ 2003;169:405-14.

4. Lasser KE, Allen PD, Woolandler SJ, et al. Timing of new black box warnings and withdrawals for prescription medications. JAMA 2002;287:2215-20.

5. Aikin KJ, Swasy JL, Braman AC. Patient and physician attitudes and behavior associated with DTC promotion of prescription drugs - summary of FDA survey research results: final report. Beltsville (MD): FDA Center for Drug Evaluation and Research; 2004. 